This is a pre-publication draft of

\title{
In Search of Critical Thinking in Psychology: An Exploration of Student and Lecturer Understandings in Higher Education
}

Elaine Duro ${ }^{1}$, James Elander ${ }^{1}$, Frances A. Maratos ${ }^{1}$, Edward J.N. Stupple ${ }^{1 *}$ and Aimee Aubeeluck $^{2}$

${ }^{I}$ Centre for Psychological Research, University of Derby, Derby, Derbyshire, UK

${ }^{2}$ School of Nursing Midwifery and Physiotherapy, University of Nottingham, Derby, Derbyshire, $U K$

*Corresponding author:

Centre for Psychological Research

University of Derby

Kedleston Road

Derby, DE22 1GB, UK

Email: e.j.n.stupple@derby.ac.uk 
Biographies

Elaine Duro is a Counsellor/Psychotherapist and qualitative researcher. Her research interests include the long-term impact of traumatic bereavement.

Prof. James Elander is head of the University of Derby's Centre for Psychological Research. His research interests include the application of psychology to higher education, especially student writing.

Dr Frances Maratos is a Senior Lecturer at the University of Derby. Her research interests include critical thinking and the cognitive and neural mechanisms of emotion processing.

Dr Edward Stupple is a Lecturer at the University of Derby. His research interests include critical thinking and the cognitive psychology of reasoning and bias.

Dr Aimee Aubeeluck is an Associate Professor at the University of Nottingham. Her research interests include quality of life for patients and their caregivers, and communication and global learning initiatives in higher education. 
Acknowledgements: Many thanks to all the participants. The study was funded by small grants from the Higher Education Academy Psychology Network Mini-Project Scheme, and the University of Derby's Teaching Informed by Research Scheme. 


\title{
In Search of Critical Thinking in Psychology: Exploring Student and Lecturer Understandings in Higher Education
}

\begin{abstract}
This qualitative study of understandings of critical thinking in higher education aimed to identify themes that could help to demystify critical thinking and inform its more explicit incorporation in the psychology curriculum. Data collected from focus groups with 26 undergraduate psychology students and individual semi-structured interviews with four psychology lecturers were examined using thematic analysis. The same key themes were identified from both student and lecturer data: 'vague beginnings', 'conceptualizations', 'development and transitions', and 'learning strategies'. Both students and lecturers described critical thinking as implicit knowledge that develops through social interactions. The findings indicate the importance of explicit discussion about critical thinking, and could be used to inform the design and delivery of instructional methods to promote critical thinking.
\end{abstract}

Words: 119

Keywords: Critical Thinking, Assessment, Teaching Psychology, Learning, Academic Achievement 


\section{Introduction}

Critical thinking is central to learning in higher education; it should be demonstrated to meet core assessment criteria for written assignments (e.g., Elander, Harrington, Norton, Robinson, \& Reddy, 2006), and it is associated with academic achievement and employability (Halx \& Reybold, 2005). However, many students struggle to understand critical thinking and demonstrate it in their assignments (e.g., Kreth, Crawford, Taylor \& Brockman, 2010), and Halonen (1995) argued that critical thinking is a mystified process that requires greater examination and questioning. Standard definitions often do not make its meaning very clear or explicit, for example one cross-disciplinary expert consensus defined critical thinking as "purposeful, selfregulatory judgment which results in interpretation, analysis, evaluation, and inference, as well as explanation of the evidential, conceptual, methodological, criteriological, or contextual considerations upon which that judgment is based" (Facione, 1990, p. 2).

There is also no clear consensus on whether critical thinking involves generic skills that can be applied across disciplines (Sa, West, \& Stanovich , 1999) or whether it is more closely related to specific subject knowledge (Garside, 1996). Partly for that reason, instructional interventions to improve critical thinking have sometimes been delivered in specialized courses and sometimes embedded in the disciplinary curriculum (Abrami, Bernard, Borokhovski, Wade, Surkes, Tamim, et al., 2008).

In the discipline of psychology, there is a rather similar debate about whether critical thinking instruction should focus on generic skills related to reasoning and research (Bensley, 1997; Meltzoff, 1998), or whether it can only be understood in the context of psychological theory and practice (Yanchar, Slife, \& Warne (2008). The 
present study aimed to inform strategies to improve shared understandings of critical thinking in psychology and incorporate critical thinking in a more explicit way in the Psychology curriculum. We used qualitative methods to explore and describe students' and lecturers' beliefs and understandings about critical thinking in depth and in their own words.

\section{Methods}

\section{Participants}

The participants were 26 undergraduate students and four lecturers in the psychology department at the University of Derby, UK. The student sample comprised 12 first-year, seven second-year and seven third-year psychology students, ranging in age from 18 to 45 years. There were five males and 21 females, which is representative of UK Psychology students generally.

The lecturer ${ }^{1}$ sample comprised four males and one female, who taught on the same psychology courses taken by the student participants and had between five and 30 years teaching experience in higher education.

\section{Data collection}

Students were interviewed in focus groups, (six student focus groups, with two in each year group), and lecturers were interviewed individually. Each session lasted approximately 45 minutes, and were all conducted by the lead author. A semi-structured interview schedule was used (see Tables 1 and 2), this was supplemented with a small

\footnotetext{
${ }^{1}$ In the UK, a 'lecturer' is a qualified, member of the academic staff of a department, for whom teaching is a significant part of their working role.
} 
number of standard probe questions in conjunction with the funnelling technique ${ }^{2}$. The interviews and focus groups were audio-recorded and transcribed verbatim.

\section{Data analysis}

We wished to identify students' and lecturers' understandings and beliefs about critical thinking, so the research was conducted from a critical realist perspective, which acknowledges the constructed nature of knowledge about the world (Archer, Bhaskar, Collier, Lawson, \& Norrie, 1998) and is characterized as a process of discovery (Willig, 2008). The transcripts were analysed using thematic analysis, a qualitative method used to identify patterns of meaning in textual data (Boyatzis, 1998). We employed Braun and Clarke's six-step thematic analytic method, which involves 1) reading and re-reading transcripts to familiarise with the data, 2) generating initial codes, 3) identifying potential themes, 4) reviewing themes, 5) defining, specifying and naming the themes, and 6) writing the report (Braun \& Clarke, 2006). Reliability of the analysis of the data was achieved with 'investigator triangulation'; to allow cross validation $\&$ transparency to occur during the data interpretation process (e.g., Janesick, 2000).

Insert tables 1 and 2 about here

\section{Results}

Four main themes emerged from the data analysis. These were labeled 'vague beginnings', 'conceptualizations', 'development and transitions', and 'learning

\footnotetext{
${ }^{2}$ The funnelling technique is the process of starting with a broad question and then focusing on an element of the answer to request further detail (Smith \& Osborn 2003).
} 
strategies'. Each theme represented the understandings and beliefs of both students and lecturers, with differences between student and lecturers incorporated within rather than between themes. In this section, we present a narrative analysis of the major themes that emerged from the analysis, together with brief extracts from the transcripts to illustrate each theme.

\section{Vague beginnings}

This theme dealt with students' first experiences with the concept of critical thinking, and lecturers and students' expectations of it. Students' initial understandings and expectations were very vague, with many expressions of failing to understand both what critical thinking is, and how to do it:

To be honest, with not understanding it, I wouldn't have taken it in as anything important, [...] it didn't have a meaning (Third year student)

Everybody says to do it, but nobody actually says how to do it (Second year student)

One issue for lecturers was uncertainty about how much critical thinking needed to be explained and the extent to which it could be made explicit: 
It's a term which is banded around quite a lot, and I have used it a lot without much thought. It's one of those things everyone understands don't they, it's obvious isn't it? (Lecturer 3)

This theme suggests that students need clearer, more explicit guidance about what critical thinking is and how to do it, but also includes lecturer understandings that challenged the need to make the meaning of critical thinking more explicit.

\section{Conceptualisations}

This theme dealt with understandings of the meaning of critical thinking. A dominant view expressed by both students and lecturers was that critical thinking was an intuitive ability that could not be explicitly taught:

I don't think it is something that you can necessarily teach, you have either got it or you haven't (Second year student)

I have always been taught to, like, step back, look at the big picture, and analyse things properly, when I'm doing anything. (First year student)

A lot of good students will grasp as to what is necessary, but I think they have to do it almost intuitively (Lecturer 2)

Lecturers saw critical thinking in terms of reasoning skills, or identifying relations between ideas and concepts: 
It's being less passive with respect to the information, actively relating pieces of information to one another, and explore those relationships and follow on with the consequences of those (Lecturer 3)

Both students and lecturers gave explanations that emphasised the relationship between critical thinking and subject knowledge:

I don't think you can properly critically evaluate [...] something that you don't understand very well [...] Knowing generally how to do critical thinking better [...] would probably help, but without knowing much about that topic, I don't think you can do that well in it! (Third year student)

I think a strong component of it [...] is scientific literacy. It's the ability to understand and evaluate information, and to then re-interpret that information as necessary. So at a very basic level, understand complex information, okay, evaluate that information, that's where the critical thinking comes in (Lecturer 3)

Both students and lecturers also gave descriptions of critical thinking that emphasised its transferable nature and relevance outside academic life:

Once you have left university, if you have got critical thinking nothing should stay the same, everything should be continually improving (Second year student) 
You can examine a design of a study, uncover methodological flaws [...] Those are the sort of transferable skills, which aren't just about Psychology experiments, but are important for daily life (Lecturer 3)

Both students and lecturers described critical thinking in terms of intuitive or implicit skills that were both generic and related to subject knowledge. The understandings expressed in this theme explain to some extent, the lack of understanding described in the previous theme.

\section{Development and transitions}

This theme dealt with the ways in which critical thinking developed over time and with educational experience. Students described how their understanding of critical thinking developed slowly, over time, often in quite informal ways:

You know it doesn't come easily, it takes time to learn (Third year student)

I think it was quite difficult at first, but I think it does get easier the more you get used to thinking in that way yeah [...] You start evaluating everything, criticizing everything, and things (First year student) 
Students also described how their understanding of how to demonstrate critical thinking in written assignments developed fully only towards the end of their degree programme:

When I got feedback, I thought, how do you critically analyze then? Because I thought that I had (Second year student)

When you come to that final stage in your writing [...] all of the little examples, the essays all the way up, they have prepared you all the way, to write in different little ways (Third year student)

This theme demonstrates that understanding and acquiring critical thinking skills is part of an evolving learning process, with the ability to demonstrate critical thinking in assessed assignments taking place towards the end of that process.

\section{Learning strategies}

This theme focused on students' and lecturers' beliefs and experiences about how critical thinking could be developed or promoted. One element of this was about the value of explicit demonstration and explanation:

It needs to be [...] a focus for a lecture and workshop [...]. So that you actually get some feedback on 'this is what you did right, this is what you did wrong, and this is where you need to take it next.' (Second year student) 
I generally work best if I have got an example, this is Critical Thinking, then I can just see what it is and apply it myself. (First year student)

Maybe just literally to demonstrate or show them or by role play an activity or whatever, to show them what is a good example of critical debate or critical argument (Lecturer 4)

Lecturers and students agreed about the way critical thinking develops from social interactions rather than solitary cognitive activity:

First of all the students need to engage, to be willing to talk and be argumentative with each other [...] there has to be some critical thinking there, in order for someone to venture forward an argument ... (Lecturer 3)

I think talking to people has helped me an awful lot, just getting together in groups and talking about things (First year student)

Importantly this theme identified active learning strategies to increase critical thinking, with lecturers and students both advocating the value of structured group exercises as a useful learning tool.

\section{Discussion}


To sum, both students and lecturers regarded critical thinking as a complex activity that is linked to subject-specific knowledge and generic thinking skills. They described critical thinking as an intuitive skill that was difficult to explain explicitly, and emphasised the importance of examples, structured activities and social interaction in its development. Students found demonstrating critical thinking in their written assignments especially challenging, and described how their understanding and ability developed slowly in the absence of formal instruction. The findings help to understand why and how critical thinking often remains a 'mystified concept' (Halonen, 1995), and suggest that it continues to be an under-analyzed area of education. The respondents also suggested potential approaches for efforts to demystify and promote critical thinking.

The primary need identified was for more explicit explanation and instruction about critical thinking. This is consistent with evidence that critical thinking can be enhanced through instructional interventions (Abrami et al., 2008), and evidence that explicit teaching of critical thinking is more effective than implicitly embedding critical thinking skills within other tasks (e.g., Halpern, 2003). A number of taxonomies and stepby-step guides to critical thinking in psychology exist already (e.g., Halpern, 2007), but our findings indicate that the value of such material could be enhanced by more active interaction, modelling and informal discussion about critical thinking, consistent with other evidence about the value of social interaction for learning (Tinto, 1997). We therefore argue for existing taxonomies of critical thinking (e.g., Halpern, 2007) to be introduced to students at points when there are opportunities for discussion and for considering critical thinking alongside the disciplinary learning outcomes and assignments for assessment. 
A key target for instructional exercises on critical thinking might be to challenge the attitude of 'you have either got it or you haven't' and promote the view of critical thinking as a complex skill that can be developed through practice, so that students are encouraged to value critical thinking and to become more active, analytic thinkers.

Critical thinking is related to core assessment criteria for written assignments (Elander et al., 2006), so it is possible that structured interactive exercises developed to improve student understanding and ability in relation to core assessment criteria such as critical evaluation and development of argument (Harrington et al., 2006) could be adapted to focus on critical thinking. This approach would involve small group work and discussion of examples, and would focus on the way that critical thinking is evidenced for student assessment. It would therefore address the issues raised by students in the present study about demonstrating critical thinking in written assignments.

In conclusion, the findings help to understand how and why critical thinking has often continued to puzzle students and lecturers in psychology. These insights can inform structured efforts to promote critical thinking that combine explicit explanations and definitions with interactive exercises. 


\section{References}

Abrami, P.C., Bernard, R.M., Borokhovski, E., Wade, A., Surkes, M.A., Tamim, R., \& Zhang, D. A. (2008). Instructional interventions affecting critical thinking skills and dispositions: A stage one meta-analysis. Review of Educational Research, 78(4), 1102-1134.

Archer, M., Bhaskar, R., Collier, A., Lawson, T., \& Norrie, A. (1998). Critical Realism: Essential Readings, London: Routledge.

Bensley, D. A. (1997). Critical thinking in psychology: A unified skills approach. Pacific Grove, CA: Brooks/Cole.

Boyatzis, R. E. (1998). Transforming Qualitative Information: Thematic analysis and code development. Sage: London.

Braun, V. \& Clarke, V. (2006). Using thematic analysis in psychology. Qualitative Research in Psychology, 3, 77-101.

Elander, J., Harrington, K., Norton, L. Robinson, H. \& Reddy, P. (2006). Complex skills and academic writing: a review of evidence about the types of learning required to meet core assessment criteria. Assessment and Evaluation in Higher Education, 31, 71-90.

Facione, P. A. (1990). Critical Thinking: A Statement of Expert Consensus for Purposes of Educational Assessment and Instruction. Millbrae, CA: California Academic Press. (ERIC document ED 315-423)

Garside, C. (1996). Look who's talking: a comparison of lecture and group discussion teaching strategies in developing critical thinking skills. Communication Education, 45, 212-227. 
Halpern, D.F. (2003). Thought and Knowledge: An Introduction to Critical Thinking (4th ed.). Mahwah,NJ: Lawrence Erlbaum Associates

Halpern, D.F. (2007). The Nature and Nurture of Critical Thinking. In R.J. Sternberg, H. L. Roediger \& D. F. Halpern. Critical Thinking in Psychology. Cambridge: Cambridge University Press.

Halonen, J. S. (1995). Demystifying Critical Thinking. Teaching of Psychology, 22 (1), $75-81$.

Harrington, K., Norton, L., Elander, J., Lusher, J., Aiyegbayo, O., Pitt, E., Robinson, H., \& Reddy, P. (2006). Using Core Assessment Criteria to Improve Essay Writing. In C. Bryan \& K. Clegg (Eds.), Innovative Assessment in Higher Education (pp. 110-119). London: Routledge.

Halx, M. D., \& Reybold, L. E. (2005). A pedagogy of force: Faculty perspectives of critical thinking capacity in undergraduate students. Journal of General Education, 54, 293-315.

Janesick, V. J. (2000). The choreography of qualitative research design: Minuets, improvisations, and crystallization. In N. K. Denzin \& Y. S. Lincoln (Eds.), Handbook of qualitative research $\left(2^{\text {nd }}\right.$ ed., pp. 379-399). Thousand Oaks, CA: Sage.

Kreth, M. Crawford, M. A., Taylor, M., \& Brockman, E. (2010). Situated assessment: Limitations and promise. Assessing Writing, 15 (1), 40-59.

Meltzoff, J. (1998). Critical Thinking about Research: Psychology and Related Fields. Washington, DC: American Psychological Association. 
Sá, W. C., West, R. F., \& Stanovich, K. E. (1999). The domain specificity and generality of belief bias: Searching for a generalizable critical thinking skill. Journal of Educational Psychology, 91, 497-510.

Smith, J. A. \& Osborne, M. (2003). Interpretative Phenomenological Analysis. In: Smith, J. A. Qualitative Psychology: A Practical Guide to Research Methods, pp. 51-80. London. Sage Publications Limited.

Tinto, V. (1997). Classrooms as communities: exploring the educational character of student persistence, Journal of Higher Education, 68, 599-623.

Willig, C. (2008) Introducing Qualitative Research Methods in Psychology. Second Edition. Maidenhead: McGare Hill/Open University Press

Yanchar, S.C., Slife, B.D., \& Warne, R. (2008). Critical thinking as disciplinary practice. Review of General Psychology, 12, 265-281. 
Table 1. Focus Group Questions for Students

'What does the phrase "critical thinking" mean to you?'
'How do you think 'critical thinking"' is applicable to students who are entering Higher
Education?'
'Can you recall when you first heard the term 'critical thinking" being used?'
'When the term "critically discuss" appears in an assignment title what do you think you
are being asked to do?'
'What do you think the term "critical thinking" means to your lecturers here at the
University?'
'How do you think students demonstrate "critical thinking" in their written work and
assignments?'
'When you are faced with the task of demonstrating "critical thinking" within your work
and assignments, how complex do you find this task to achieve?'
'How do you think students could improve their "critical thinking" skills?'
'What type of resources do you think would be especially useful in helping to improve
'Dour "critical thinking" skills?'


Table 2 Interview Questions for Staff

'What does the phrase "critical thinking" mean to you?'
'How do you think "critical thinking" is applicable to students who are entering Higher
Education?'
'How applicable do you think "critical thinking" is to psychology?'
'Do you think the application of "critical thinking" may differ between different areas of
study, say for example between psychology and civil engineering students?'
'How do you think students can demonstrate "critical thinking" in their written work and
assignments?'
'How do you think students could improve their "critical thinking" skills?'
'When you ask students to use "critical discussion" within their assignments, what are
you requesting them to do?
'What do you think the term "critical thinking" means to your students here at the
University?'
'When faced with the task of demonstrating "critical thinking" skills within their work,
how difficult is it for your students to achieve that?'
'What type of resources do you think would be especially useful in helping to improve
your students "critical thinking" skills?'
'How does "critical thinking" affect the way you teach here at the university?'

Word count: 2206 (excluding abstract, title, tables and references). 